\title{
Water retention properties of the clay in soils developed on clayey sediments: Significance of parent material and soil history
}

\author{
A. BRUAND ${ }^{\mathrm{a}}$ \& D. TESSIER ${ }^{\mathrm{b}}$ \\ ${ }^{a}$ INRA, Unité de Science du Sol - SESCPF, Centre de Recherche d'Orléans, Avenue de \\ la Pomme de Pin, Ardon BP 20619, 45166 Olivet Cedex, and ${ }^{\mathrm{b}}$ INRA Unité de Science \\ du Sol, Centre de Recherche de Versailles, Route de St Cyr, 78026 Versailles Cedex, \\ France
}

Correspondence: A. Bruand. E-mail: ary.bruand@orleans.inra.fr

\section{Summary}

We have investigated the water retention properties of clayey subsoils horizons according to the variation of clay characteristics. The horizons studied developed on a large range of age and facies of calcareous or calcium saturated clayey sediments. The water retention properties have been studied from $-10 \mathrm{hPa}$ to $-15000 \mathrm{hPa}$ water potential using small clods collected in winter when swelling is at a maximum and water content close to field capacity. The specific water content and volume of the clods at field conditions, their specific water content at $-15000 \mathrm{hPa}$ water potential, the clay content, the organic carbon content, the cation exchange capacity, the $\mathrm{N}_{2}$-BET surface area and calcareous content were measured. The clay fabric, which is the spatial distribution of the elementary clay particles, was quantified when the soil was close to field capacity and we could attribute the whole pore volume to the porosity of the clay fabric. Our results show that the water retention properties of the clay varies greatly 
from one soil to another with respect to the clay fabric. The variation of the latter depends on the cation exchange capacity, the size of elementary particles and hydric stress history of the clay. We show that the water retention properties of the studied clayey soils vary according to the clay content and fabric, the latter being related either to parent material fabric or to both the hydric history of the soil and size of the elementary clay particles.

\section{Propriétés de rétention en eau de l'argile au sein de sols développés sur sédiments} argileux : Importance de l'héritage du matériau parental et de l'histoire du sol

\section{Résumé}

Nous avons étudié les propriétés de rétention en eau d'horizons B argileux en fonction des caractéristiques de l'argile. Les horizons étudiés proviennent de sols développés sur des sédiments argileux calcaires ou calciques d'âge et de faciès très variés. Les propriétés de rétention en eau ont été étudiées pour un potentiel de l'eau variant de -10 hPa à -15 000 hPa en utilisant de petites mottes collectées en hiver lorsque les sols sont à leur gonflement maximal et que la teneur en eau est proche de la capacité au champ. La teneur en eau et le volume spécifique des mottes lors du prélèvement, leur teneur en eau à un potentiel de l'eau de $-15000 \mathrm{hPa}$, la teneur en argile, la teneur en carbone organique, la capacité d'échange cationique, la surface BET et la teneur en calcaire ont été déterminées. Le mode d'assemblage des particules d'argile a été estimé en considérant qu'à proximité de la capacité au champ toute la porosité des mottes pouvait être attribuée à des pores résultant du mode d'assemblage des particules d'argile. Nos résultats montrent que les propriétés de rétention en eau de l'argile varient énormément d'un sol à l'autre selon le mode d'assemblage des particules d'argile. Les variations du mode d'assemblage des particules d'argile dépendent de la capacité d'échange cationique, de la taille des particules élémentaires et de l'histoire des contraintes hydrique de la phase argileuse. Nous montrons ainsi que les propriétés de rétention en eau des sols argileux étudiés s'expliquent alors par des différences de teneur en argile et de mode d'assemblage des particules élémentaires d'argile, ce dernier étant 
lié soit à un assemblage des particules d'argiles hérité du matériau parental, soit à la fois à l'histoire hydrique du sol et à la taille des particules élémentaires d'argile.

\section{Introduction}

The physical properties of clayey soils are strongly related to both clay content and clay characteristics such as the mineralogy, the size of elementary particles and the nature of the cations saturating the electrical charges at the surfaces of particles (Tessier \& Pédro, 1987; Quirk, 1994). The clay characteristics control the physico-chemical properties of the clay and particularly the interparticle swelling, i.e. the clay fabric which corresponds to the spatial distribution of the elementary clay particles when the water potential and the nature of the cation vary. Tessier (1984) and Tessier et al. (1992) studied the water retention properties of pure clays and demonstrated that the clay fabric at a given water potential is closely related to the former characteristics of the elementary clay particles but also to the stress history. Bruand \& Zimmer (1992) studied the water retention properties of clayey soils and discussed the role of both the clay mineralogy and stress history, but the contributions of these two sets of characteristics to the clay fabric variation remains under discussion.

For buried clayey sediments, the elementary fabric varies with the burial depth, and this variation would explain the differences of hydraulic properties that are recorded for clayey sediments, although there is no variation of both the clay mineralogy and cation saturating the electrical charges at the surface of the clay particles (Vasseur et al., 1995). Skempton (1970) showed that the elementary fabric is related to the effective stress as earlier defined by Terzaghi \& Peck (1948). Thus, the variation of the elementary fabric can be explained in terms of material consolidation as reviewed in some details by Meade (1964) and Rieke \& Chilingarian (1974). For soils we do not know to which stage the soil fabric is related to the stress history of the parent material and soil itself and what are the consequences on the hydraulic properties. In this study, we analyse the water retention properties of the non-extracted clay in clay soils 
developed on clayey sediments. Our results enable us to discuss water retention properties according to the clay fabric which depends upon clay characteristics and stress history, and more generally according to the parent material heritage and soil history.

\section{Material and methods}

The soils studied are Cambisols, Luvisols and Planosols (FAO-UNESCO, 1988) developed on a large range of age and facies of parent materials that are calcareous or calcium saturated clayey sediments (Table 1). The clay mineralogy of most of the soils selected was studied by Robert et al. (1991). Altogether we had 37 clayey subsoil horizons. The soil water regime was described according to the drainage classes as earlier defined by the Soil Survey of England and Wales (see Table 6-16 in McRae, 1998) Undisturbed samples $50-100 \mathrm{~cm}^{3}$ in volume were collected in winter when the soil was near to field capacity and as a consequence near maximum swelling. The samples were stored at $5^{\circ} \mathrm{C}$ to reduce biological activity and in sealed plastic containers to avoid water loss. Particle-size distribution was measured using the pipette method after pre-treatment with hydrogen peroxide and sodium hexametaphosphate (Robert \& Tessier, 1974). Cation exchange capacity (CEC, $C_{\mathrm{e}}$ in mmol + per g of oven-dried soil) was measured using ammonium acetate buffered at $\mathrm{pH}$ 7.0, and organic carbon by oxidation using an excess amount of potassium bichromate in a sulphuric acid controlled at $135^{\circ} \mathrm{C}$ (Baize, 2000). The $\mathrm{N}_{2}$-BET surface area ( $S$ in $\mathrm{m}^{2}$ per g of ovendried soil) was measured on a ground sample after drying at $180^{\circ} \mathrm{C}$ by using an ASAP 2000 Micromeritics (Fripiat et al., 1971). Results were expressed on the mass basis after dehydration at $105^{\circ} \mathrm{C}$. Clods $5-8 \mathrm{~cm}^{3}$ in volume were separated by hand from the stored samples. We measured the specific water content $\left(W_{\mathrm{f}}\right.$, in $\mathrm{g}$ of water per $\mathrm{g}$ of oven-dried soil), and the specific volume of the clods at field conditions $\left(V_{\mathrm{f}}\right.$, in $\mathrm{cm}^{3}$ per $g$ of ovendried soil) by using the kerosene method (Monnier et al., 1973). Specific water content ( $W$, g of water per g of oven-dried soil) at water potentials, $\Psi,-10,-33,-100,-330$, $-1000,-3300,-10000$ and $-15000 \mathrm{hPa}$ was measured using pressure membrane or pressure plate apparatus. Clods were placed on a paste made of $<2 \mu$ m particles of 
kaolinite to establish continuity of water between the clods and the membrane or the porous plate of the apparatus (Bruand et al., 1996). At -15 $000 \mathrm{hPa}$ water potential we also measured the specific volume of the clods ( $V_{15000}$ in $\mathrm{cm}^{3}$ per $\mathrm{g}$ of oven-dried soil) as we did with the clods at field conditions. Specific water content and volume were expressed with respect to the dry mass of the sample after oven-drying at $105^{\circ} \mathrm{C}$ for 24 hours. Fifteen clods were used for each sample to determine the mean values of $V_{\mathrm{f}}$, $V_{15000}, W_{\mathrm{f}}$ and $W$ at the different values of water potential.

\section{Results and discussion}

Cation exchange capacity and $N_{2}$-BET surface area of the clay

The horizons exhibited a large range of clay content ( $C$, in g per g of oven-dried soil), $C_{\mathrm{e}}, S, W_{\mathrm{f}}$ and $V_{\mathrm{f}}$ (Tables $1 \& 2$ ). Most of the horizons are non-calcareous (29 horizons) and for the others, $\mathrm{CaCO}_{3} \leq 0.095 \mathrm{~g} \mathrm{~g}^{-1}$. The organic carbon content ranged from $0.13 \times 10^{-2}$ (horizon 16) to $1.18 \times 10^{-2} \mathrm{~g} \mathrm{~g}^{-1}$ (horizon 7). The water retention properties showed a wide variety of water content between -10 and $-15000 \mathrm{hPa}$ water potential (Table 2).

Because the subsoil horizons contained little organic carbon (Table 1), we assumed that the contribution of the organic matter to the cation exchange capacity is negligible compared with the cation exchange capacity of the clay. Thus we calculated the cation exchange capacity of the clay $\left(C_{\mathrm{cl}}\right.$, in $\mathrm{mmol}_{+}$per g of oven-dried clay) as follows:

$$
C_{\mathrm{cl}}=C_{\mathrm{e}} / C \text {. }
$$

Results showed that $C_{\mathrm{cl}}$ ranged from 0.227 (horizon 17) to $0.666 \mathrm{mmol}_{+} \mathrm{g}^{-1}$ (horizon 21) which corresponded to clay with large kaolinite (see sample 12 in Robert et al., 1991) and smectite (see sample 10 in Robert et al., 1991) contents, respectively (Table 3). The $\mathrm{N}_{2}$-BET surface area can be attributed to the clay fraction solely, the contribution of silt and sand fractions being negligible for clay soils. Thus we calculated the $\mathrm{N}_{2}$-BET surface area of the clay $\left(S_{\mathrm{cl}}\right.$, in $\mathrm{m}^{2}$ per $\mathrm{g}$ of oven-dried clay) as follows:

$$
S_{\mathrm{cl}}=S / C \text {. }
$$

Results showed that $S_{\mathrm{cl}}$ ranged from 53.1 (horizon 18) to $139.0 \mathrm{~m}^{2} \mathrm{~g}^{-1}$ (horizon 21) (Table 3) and that there is a close relation between $C_{\mathrm{cl}}$ and $S_{\mathrm{cl}}$ (Figure 1). The closeness 
of the latter and the small value of $C_{\mathrm{cl}}$ when $S_{\mathrm{cl}}=0$ are consistent with the results recorded by Robert et al. (1991) who made X-ray diffraction, transmission electron microscopy and cation exchange capacity measurements on the clay extracted from the soils studied. Indeed, these authors showed that except for horizon 17 , which was the only horizon with a large kaolinite content, clay was essentially 2:1 clay and the increase in $C_{\mathrm{cl}}$ corresponded to a decrease in the number of layers that constitute the elementary clay particles. In other respects, the horizon 17 is the point which is the most distant from the regression line in Figure 1 . Thus, the close relation between $C_{\mathrm{cl}}$ and $S_{\mathrm{cl}}$ would indicate also that the cation exchange capacity results mainly from the contribution of the external surface of the elementary clay particles and that the electrical charge density of this surface can be considered as roughly constant.

\section{Clay fabric}

The clay fabric can be expressed numerically using the pore volume associated with the clay. Indeed the specific volume of the clods at the field conditions $\left(V_{\mathrm{f}}\right)$ is related to the specific volume of solid phase $\left(V_{\mathrm{s}}\right.$, in $\mathrm{cm}^{3}$ per g of oven-dried soil) and to the specific volume of pores ( $V_{\mathrm{p}}$, in $\mathrm{cm}^{3}$ per $\mathrm{g}$ of oven-dried soil) as follows:

$$
V_{\mathrm{f}}=V_{\mathrm{s}}+V_{\mathrm{p}} \text {. }
$$

If $V_{\mathrm{s}}$ is assumed constant, then changes in $V_{\mathrm{f}}$ can be attributed solely to changes in the volume of pores. Thus, $V_{\mathrm{p}}$ can be calculated for each sample using $V_{\mathrm{s}}=0.377 \mathrm{~cm}^{3} \mathrm{~g}^{-1}$ which corresponds to a particle density of 2.65. Then because the subsoil horizons were close to field capacity at the sampling date, we assumed that for the centimetric clods the volume of cracks and biopores is negligible compared with the pore volume of the clay, i.e. related to the packing of the clay particles. That assumption is consistent with the small difference between $V_{\mathrm{p}}$ at field conditions which was calculated with Equation (3) and the volume of water within the clods at the same condition using a water density of 1 (Table 2). Indeed, that difference was $0.006 \mathrm{~cm}^{3} \mathrm{~g}^{-1}$ (standard error $=0.003 \mathrm{~cm}^{3} \mathrm{~g}^{-1}$ ) and corresponded to $2 \%$ of the mean $V_{\mathrm{p}}$ calculated for the set of horizons at the field conditions. Then we calculated the specific pore volume of the clay $\left(V_{\mathrm{p}, \mathrm{cl}}\right.$, in $\mathrm{cm}^{3}$ per $\mathrm{g}$ of oven-dried clay) as follows: 


$$
V_{\mathrm{p}, \mathrm{cl}}=V_{\mathrm{p}} / C \text {. }
$$

The quantity $V_{\mathrm{p} \text {, cl }}$ can be considered as a quantitative expression of the clay fabric (Table 2). It ranges from 0.337 (horizon 18) to $1.484 \mathrm{~cm}^{3} \mathrm{~g}^{-1}$ (horizon 9) and is not significantly $(P=0.05)$ related to $C_{\mathrm{cl}}$ or $S_{\mathrm{cl}}$. This lack of relation between $V_{\mathrm{p} \text {, cl }}$ and $C_{\mathrm{cl}}$ or $S_{\mathrm{cl}}$ suggests that the clay fabric varies independently of the size and mineralogy of the clay particles.

\section{Water retention properties of the clay}

As for the pore volume of the clods, see Equation (4), and on the basis of the same assumptions, the water retained was considered as located within pores of the clay fabric, whatever the water potential. Thus the difference of water retention properties between the samples resulted from variation of both the clay content and water retention properties of the clay. The latter were calculated by correcting for $C$ the water content of the horizon $(W)$ at the different water potentials as follows:

$$
W_{\mathrm{cl}}=W / C \text {, }
$$

where $W_{\mathrm{cl}}$ is expressed in $\mathrm{g}$ of water per $\mathrm{g}$ of oven-dried clay. Calculation of $W_{\mathrm{cl}}$ between -10 and $-15000 \mathrm{hPa}$ water potential using Equation (5) is consistent with the small difference between $V_{\mathrm{p}}$ at $-15000 \mathrm{hPa}$ and the volume of water within the clods at that potential and using a water density of 1 . Indeed that difference was $0.010 \mathrm{~cm}^{3} \mathrm{~g}^{-1}$ (standard error $=0.001 \mathrm{~cm}^{3} \mathrm{~g}^{-1}$ ) which was $4 \%$ of $V_{\mathrm{p}}$ at $-15000 \mathrm{hPa}$. Thus as for the clods at field conditions, the clods can be considered as being saturated at $-15000 \mathrm{hPa}$ water potential.

Analysis of $W_{\mathrm{cl}}$ variation at every water potential shows a close relation between $W_{\mathrm{cl}}$

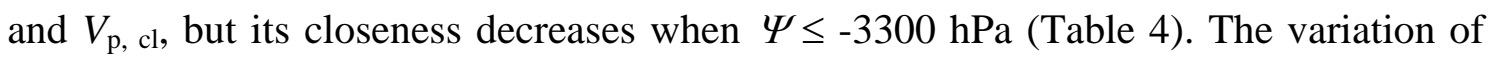
$W_{\mathrm{cl}}$ between -10 and $-15000 \mathrm{hPa}\left(\Delta W_{\mathrm{cl}}\right)$ ranged from 0.048 (horizon 18$)$ to $0.803 \mathrm{~g} \mathrm{~g}^{-1}$ (horizon 9) (Table 3). For further analysis of the water retention curves with respect to

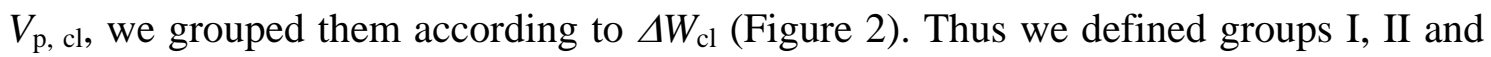
III which corresponded to horizons for which $\Delta W_{\mathrm{cl}}>0.250 \mathrm{~g} \mathrm{~g}^{-1}$, $0.150 \leq \Delta W_{\mathrm{cl}} \leq 0.250 \mathrm{~g} \mathrm{~g}^{-1}$ and $\Delta W_{\mathrm{cl}}<0.150 \mathrm{~g} \mathrm{~g}^{-1}$, respectively. For every group of horizons we calculated the mean slope of the water retention curve between two 
successive water potentials (Table 5). For horizons belonging to group III, the absolute value of the slope is roughly constant and small for $\Psi>-10000 \mathrm{hPa}$ and it increases slightly for $-10000 \geq \Psi \geq-15000 \mathrm{hPa}$ but remains $<0.100 \mathrm{~g} \mathrm{~g}^{-1}$ per unit of $\log (-\Psi)$ (Table 5). For horizons belonging to group II, water release by the clay is more progressive. The absolute value of the slope remains roughly constant and small for $\Psi>-330 \mathrm{hPa}$, and it increases between $-330 \geq \Psi \geq-15000 \mathrm{hPa}$ to its largest value between -10000 and $-15000 \mathrm{hPa}$. It is $>0.100 \mathrm{~g} \mathrm{~g}^{-1}$ per unit of $\log (-\Psi)$ when $1000 \leq \Psi \leq-15000 \mathrm{hPa}$ (Table 5). Finally, for horizons belonging to group I, the absolute value of the slope increases when $\Psi$ decreases within the whole range of $\Psi$ studied and becomes $>0.100 \mathrm{~g} \mathrm{~g}^{-1}$ per unit of $\log (-\Psi)$ when $\Psi \leq-330 \mathrm{hPa}$. Thus water is released by the clay in the whole range of water potential studied. There is a great variation of $\Delta W_{\mathrm{cl}}$ between horizons belonging to group I, clay of horizons 9 and 10 releasing great amount of water even a high water potential.

For group II, the position of every curve in the graph can be discussed in relation to $C_{\mathrm{cl}}$. For the horizons 35 and $19, C_{\mathrm{cl}}$ was 0.624 and $0.310 \mathrm{mmol}_{+} \mathrm{g}^{-1}$, respectively, which was the smallest and greatest $C_{\mathrm{cl}}$ in that group (Figure 2b, Table 3). For the set of horizons $1,2,3,8$ and $31, C_{\mathrm{cl}}$ ranged from 0.442 to $0.609 \mathrm{mmol}_{+} \mathrm{g}^{-1}$, and the mean value was $0.525 \mathrm{mmol}_{+} \mathrm{g}^{-1}$ (standard error $=0.010 \mathrm{mmol}_{+} \mathrm{g}^{-1}$ ). For the set of horizons $15,16,24,26,27,28,29,33$ and 37 of which the curves lay below the former set of curves, $c e c_{\mathrm{cl}}$ ranged from 0.370 to $0.522 \mathrm{mmol}_{+} \mathrm{g}^{-1}$, and the mean value was 0.418 $\mathrm{mmol}_{+} \mathrm{g}^{-1}$ (standard error $=0.009 \mathrm{mmol}_{+} \mathrm{g}^{-1}$ ). Thus results show a clear trend indicating that water retained by clay increased with $C_{\mathrm{cl}}$ for group II. For groups I and III, the position of the curves in the graph is not related to $C_{\mathrm{cl}}$. Indeed for group I, the horizons 9 and 34 which had close $C_{\mathrm{cl}}$ exhibited different water retention curves, and horizons 4 and 36 which had very different $C_{\mathrm{cl}}$ (Table 3 ) exhibited close water retention curves (Figure 2a). For group III, the set of horizons 5, 13, 14, 21, 22 and 25 with close water retention curves corresponded to highly variable $C_{\mathrm{cl}}$ ranging from 0.320 to $0.666 \mathrm{mmol}_{+} \mathrm{g}^{-1}$ (Figure 2c, Table 3). 


\section{Water retention and soil mechanics}

These results can be discussed in terms of soil mechanics. In soil mechanics, the consolidation curve of a saturated clay material corresponds to a decrease in its void ratio with the application of an external load which is greater than the greatest external stress recorded earlier by the material. With regard to the fabric, consolidation corresponds to a new arrangement of the particles.

Graphically, the evolution of the void ratio ( $e$, ratio of the volume of voids to the volume of solid) as a function of the effective stress in normally consolidated clays is the consolidation curve (Figure 3, path $\mathrm{ABE}$ ) which separates the space of mechanically unstable states from the space of mechanically metastable states (Parker, 1986; Charpentier \& Bourrié, 1997). When a clayey material is normally consolidated up to an effective stress of $\sigma_{1}^{\prime}$ and then unloaded, the evolution of $e$ for a next loading is described by the path CD which corresponds to the loading of an overconsolidated material $\left(\sigma^{\prime}<\sigma_{1}^{\prime}\right)$ (Figure 3) and then by the path DE when $\sigma^{\prime}>\sigma_{1}^{\prime}$ which corresponds to normal consolidation (Bradford \& Gupta, 1986). Because the horizons were considered as being saturated within the range of water potential studied, the water retention curves can be considered as consolidation curves under hydric stress. Thus, for the horizon studied, $\Psi$ is related to the pneumatic pressure that was applied to the clods in the laboratory to determine the water retention properties as follows (Sposito, 1981):

$$
\Psi=-\left(P-P^{0}\right),
$$

where $P^{0}$ is the reference state $\left(10^{5} \mathrm{~Pa}\right), P-P^{0}$ is the pressure applied to the clods in $\mathrm{Pa}$. If we consider that when a clod reaches the equilibrium under a pressure of $P-P^{0}$, the stress that is applied to the solid phase corresponds to the effective stress $(\sigma)$, then we have

$$
\sigma^{\prime}=-\Psi,
$$

which gives by combining Equations (6) and (7)

$$
\sigma^{\prime}=\left(P-P^{0}\right) \text {. }
$$

In addition, $e$ at the different $\sigma^{\prime}$ can be calculated from $W_{\mathrm{cl}}$ since

$$
e=W_{\mathrm{cl}}\left(V_{\mathrm{w}} / V_{\mathrm{s}, \mathrm{cl}}\right)
$$


with $V_{\mathrm{w}}$, the specific volume of water in $\mathrm{cm}^{3}$ per g of water and $V_{\mathrm{s} \text {, cl }}$ the specific volume of the clay in $\mathrm{cm}^{3}$ per $\mathrm{g}$ of oven-dried clay. Thus, using $V_{\mathrm{w}}=1 \mathrm{~cm}^{3} \mathrm{~g}^{-1}$ and assuming $V_{\mathrm{s}, \mathrm{cl}}=0.377 \mathrm{~cm}^{3} \mathrm{~g}^{-1}$ (reciprocal of $2.65 \mathrm{~g} \mathrm{~cm}^{-3}$ ), the water retention curves of the clay (Figure 2) can be discussed as showing the variation of $e$ against $\sigma^{\prime}$.

Significance of the parent material heritage and hydraulic history of the soil

We can pursue the discussion above to the significance of the parent material heritage and soil history. Most of the horizons in group I belong to soils developed on recent marine, alluvial and colluvial sediments. Horizons 9 and 10 are not or only weakly affected by desiccation during the dry season because they remain wetted by a water table throughout almost all the year (Table 1). They have the properties of slightly consolidated materials, and much of the water retention curve would correspond to the normal consolidation curve as defined in soil mechanics (Figures 2a \& 3) (Charpentier, 1991; Vasseur et al., 1995). Other horizons in group I developed also on recent sediments but would be more consolidated (Figure 2a) because they are more affected by desiccation during the dry season (Table 1). The near-horizontal path of the water retention curve, which corresponds to a range of water potential with small variation of its slope, is interpreted as the water retention curve of an overconsolidated material. The water potential at which the absolute value of the slope increases clearly and becomes $>0.100 \mathrm{~g} \mathrm{~g}^{-1}$ per unit of $\log (-\Psi)$ could be interpreted as a rough estimation of the greatest effective stress that was recorded for the horizon. Thus, the effective stress is estimated as roughly ranging from 330 to $1000 \mathrm{hPa}$ for horizons of group I (Table 5), its value being smaller for horizon 9 and estimated being 100 and 330 hPa (Figure 2a).

In contrast, for the horizons of group III the mean water retention curve had a small absolute value slope within the whole range of water except between -10000 and $15000 \mathrm{hPa}$ where that absolute value of the slope slightly increases (Table 4). For such horizons, the greatest effective stress recorded by the horizon would be more than $15000 \mathrm{hPa}$. The water retention properties would be those of overconsolidated materials in the entire range of water potential studied, thereby explaining the small water extraction from -10 to $-15000 \mathrm{hPa}$ (Figure 2c). This interpretation of the results 
is consistent with the fact that most horizons belonging to group III were at the bottoms of the soil profile and showed many morphological characteristics similar to those of the parent material which was a highly consolidated sediment (Table I). The record of the greatest effective stress would be related to the presence of $\mathrm{Ca}^{2+}$ as main exchangeable cation on the external surface of the individual clay particles. Such a behaviour, which has already been observed by Tessier (1984) with calcium saturated clays, would be related to the closeness of packing of individual clay particles and consequently to the number of contact points between them for highly consolidated materials such as marls, marly limestones and molasses. The positions of the electrical charges in the tetraedral and octaedral layer would lead interparticle forces acting at these contact points and would be strong enough to restrict swelling when rewetting occurs (Quirk, 1994). This would explain the stability of overconsolidated horizons, although the size of the elementary clay particles and the electrical charge as indicated by cation exchange capacity measurements have decreased much as a result of weathering. This would explain also the lack of relation between the water retention properties of the clay and the water regime, which varied from poorly to moderately well drained (Table 1), and consequently the hydric stress history of the horizons.

Finally, for the horizons of group II, the absolute value of the slope is small for $\Psi \geq$ $330 \mathrm{hPa}$ and it increases when $\Psi<-330 \mathrm{hPa}$ to values $>0.100 \mathrm{~g} \mathrm{~g}^{-1}$ per unit of $\log (-\Psi)$ when $\Psi \leq-3300 \mathrm{hPa}$ (Table 5). Most of these horizons belong to soils moderately well drained and thus submitted to annual wetting-drying cycles that are induced by the climatic demand in the Paris Basin. In that case the pedological evolution and particularly the succession of annual wetting-drying cycles would lead to a consolidation state that corresponds roughly to an effective stress ranging from -3300 to $-10000 \mathrm{hPa}$ (Table 5). The vertical shift of the curves is related to $C_{\mathrm{cl}}$, as discussed above, and would be the consequence of variation of the swelling potential when both $S_{\mathrm{cl}}$ and $C_{\mathrm{cl}}$ increase.

\section{Conclusion}


Our results show that the water retention properties of clayey subsoil developed on calcareous or calcium saturated clayey sediments are related to both the clay content and clay fabric. When the results are discussed without any stratification there is no relation between the clay fabric and the cation exchange capacity or the surface area of the clay. Further analysis using the amount of water released by the clay between -10 and $-15000 \mathrm{hPa}$ water potential as stratification criteria enabled us to distinguish the origin of the clay fabric.

For horizons at the bottoms of the soil profile and with many morphological characteristics similar to those of the parent material, the clay fabric is related to the parent material clay fabric essentially. For most horizons in moderately well drained soils in the climate of the Paris Basin, the clay fabric seems to be related to the external surface of the clay particles and to the electrical charge density on that surface. This climate would be responsible for the consolidation characteristics of the horizons. Finally, for horizons that dry little in summer because of their soil water regime and developed on recent sediments, there is no relation between the water retention properties of the clay and its characteristics. Such horizons are more weakly consolidated sediments than subsoil horizons and the hydric stress history prevails on the clay characteristics to explain the water retention of the clay. More generally, our results accord with earlier ones of Tessier \& Pédro (1987) who showed for pure clays that the significance of clay characteristics would increase with the value of the greatest effective stress recorded by the horizon. On the other hand, the horizons that showed numerous characteristics similar to the parent material can be considered as overconsolidated materials in the whole range of water potential studied. These horizons have evolved little and were transitions between the bedrock and the soil.

Finally, the water retention curve of a horizon should be determined within the range of water potential corresponding to the overconsolidated domain. Every determination for smaller water potential would induce further consolidation of the material and an irreversible change of the clay fabric and consequently of the water retention properties. Thus the water retention properties determined would not correspond to the field behaviour of the soil under the range of wetting-drying cycles recorded by the horizon 
before the sampling. On the other hand, our results show that the sensitivity of clayey soils to irreversible evolution of their water retention properties and probably of other physical properties would increase when the greatest effective stress recorded by the soil decreases.

\section{Acknowledgements}

This work forms part of a research programme funded by the Regional Concil of the Centre Région, France. The authors gratefully acknowledge H. Gaillard (INRA Orléans), and J.F. Pessaud (INRA Chateauroux) for skilled assistance in the laboratory.

\section{References}

Baize, D. 2000. Guide des analyses en pédologie. Inra, Versailles.

Bradford, J.M. \& Gupta, S.C. 1986. Compressibility. In: Methods of Soil Analysis: Part 1, Physical and Mineralogical Methods, 2nd edn (ed. A. Klute), pp. 479-492. American Society of Agronomy, Madison, WI.

Bruand, A. 1990. Improved prediction of water-retention properties of clayey soils by pedological stratification. Journal of Soil Science, 41, 491-497.

Bruand, A., Duval, O., Gaillard, H., Darthout, R. \& Jamagne, M. 1996. Variabilité des propriétés de rétention en eau des sols: importance de la densité apparente. Etude et Gestion des Sols, 3, 27-40.

Bruand, A. \& Zimmer, D. 1992. Relation entre la capacité d'échange cationique et le volume poral dans les sols argileux: incidences sur la morphologie de la phase argileuse à l'échelle des assemblages élémentaires. Comptes Rendus de l'Académie des Sciences, Série II, 315, 223-229.

Charpentier, S. 1991. Déformation de matériaux argileux soumis à une contrainte mécanique en conditions saturées. Influence de la concentration et de la nature des solutés. Thèse de doctorat, Ecole Nationale Supérieure Agronomique de Rennes.

Charpentier, S. \& Bourrié, G. 1997. Deformation of saturated clays under mechanical and osmotic stress and its relation with the arrangement of the clays. European Journal of Soil Science, 48, 49-57. 
FAO-UNESCO 1988. Soil Map of the World. Volume 1. Revised Legend. UNESCO, Paris.

Fripiat, J., Chaussidon, J. \& Jelli, A. 1971. Chimie-physique des phénomènes de surface. Application aux oxydes et aux silicates. Masson, Paris.

Meade, R.H. 1964. Removal of water and rearrangement of particles during the compaction of the clayey sediments. Professional Paper, US Geological Survey, 450B, B1-B23, Reston, VA.

Monnier, G., Stengel, P. \& Fiès, J.C. 1973. Une méthode de mesure de la densité apparente de petits agglomérats terreux. Application à l'analyse des systèmes de porosité du sol. Annales Agronomiques, 24, 533-545.

Quirk, J.P. 1994. Interparticle forces: A basis for the interpretation of soil physical behavior. Advances in Agronomy, 53, 121-183.

Parker, J.C. 1986. Hydrostatics of water in porous media. In: Soil Physical Chemistry (ed. D.L. Sparks), pp. 209-296. CRC Press Inc., Boca Raton, Florida.

McRae, S.G. 1988. Practical Pedology. Studying Soils in the Field. Ellis Horwood Ltd, Chichester.

Rieke, H. \& Chilingarian, G.V. 1974. Compaction of Argillaceous Sediments. Development in Sedimentology, No 16, Elsevier, Amsterdam.

Robert, M., Hardy, M. \& Elsass, F. 1991. Crystallochemistry, properties and organization of soil clays derived from major sedimentary rocks in France. Clay Minerals, 26, 409-420.

Robert, M. \& Tessier D. 1974. Méthode de préparation des argiles des sols pour les études minéralogiques. Annales Agronomiques, 25, 859-882.

Sposito, G. 1981. The Thermodynamics of Soil Solutions. Oxford University Press, Oxford.

Skempton, A.W. 1970. The consolidation of clays by gravitational compaction. Quarterly Journal of the Geological Society of London, 125, 373-411.

Terzaghi, K. \& Peck, R.B. 1948. Soil Mechanics in Engineering Practice. John Wiley and Sons, Chichester. 
Tessier, D. 1984. Etude expérimentale de l'organisation des matériaux argileux. Hydratation, gonflement et structuration au cours de la dessiccation et de la réhumectation. Thèse d'Etat, Université Paris 7.

Tessier, D., Lajudie, A. \& Petit, J.C. 1992. Relation between the macroscopic behavior of clays and their microstructural properties. Applied Geochemistry, Supplement Issue No 1, 151-161.

Tessier, D. \& Pédro, G. 1987. Mineralogical characterization of 2:1 clays in soils: Importance of the clay texture. In: Proceedings of the International Clay Conference, Denver, 1985 (ed. L.G. Schultz, H. van Olphen \& F.A. Mumpton), pp. 78-84. The Clay Minerals Society, Bloomington, IN.

Vasseur, G., Djera-Maigre, I., Grunberger, D., Rousset, G., Tessier, D. \& Velde, B. 1995. Evolution of structural and physical parameters of clays during experimental compaction. Marine and Petroleum Geology, 12, 941-954. 


\section{Figures}

Figure 1 Relation between the calculated cation exchange capacity of the clay $\left(\operatorname{cec}_{\mathrm{cl}}\right)$ and the calculated $\mathrm{N}_{2}$-BET surface area of the clay $\left(S_{\mathrm{cl}}\right)$.

Figure 2 Water retention curves of the clay $\left(W_{\mathrm{cl}}\right.$ against $\log (-\Psi)$, with $\Psi$ in $\mathrm{cm}$ of water) within the subsoil clayey horizons studied. The water retention curves are grouped according to the difference of $W_{\mathrm{cl}}$ between -10 and $-15000 \mathrm{hPa}$ water potential $\left(\Delta W_{\mathrm{cl}}\right)$ : a, group I with $\Delta W_{\mathrm{cl}}>0.250 \mathrm{~g} \mathrm{~g}^{-1}$, b, group II with $0.150 \leq \Delta W_{\mathrm{cl}} \leq$ $0.250 \mathrm{~g} \mathrm{~g}^{-1}$ and c, group III with $\Delta W_{\mathrm{cl}}<0.150 \mathrm{~g} \mathrm{~g}^{-1}$.

Figure 3 Evolution of the void ratio $(e)$ as a function of the effective stress $(\sigma)$. Path ABE corresponds to normal consolidation, paths $\mathrm{BC}$ to unloading after consolidation up to $\sigma_{1}^{\prime}$ and paths $\mathrm{CD}$ to the loading of an overconsolidated material for $\sigma^{\prime}<\sigma_{1}^{\prime}$. 


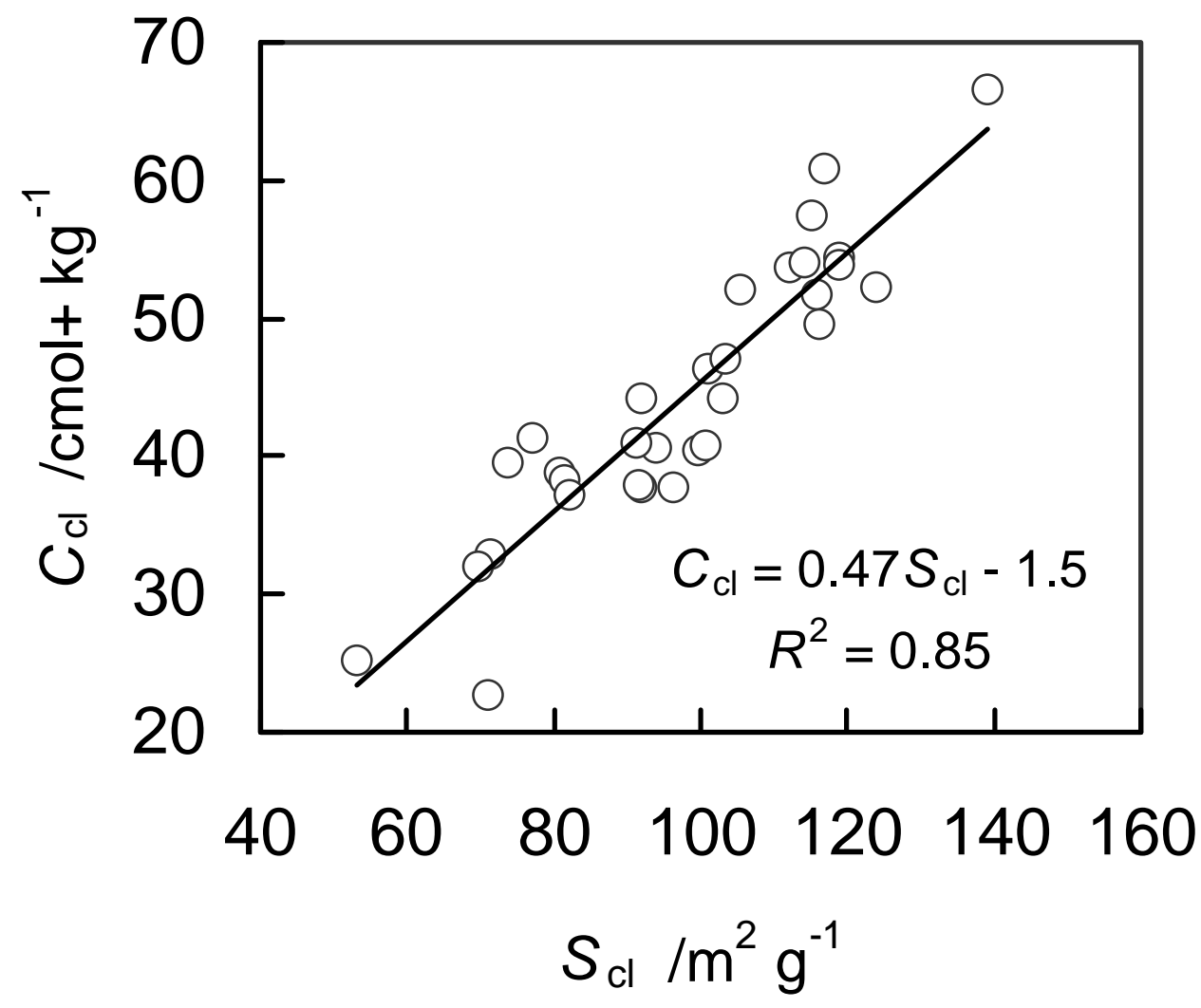

Figure 1 


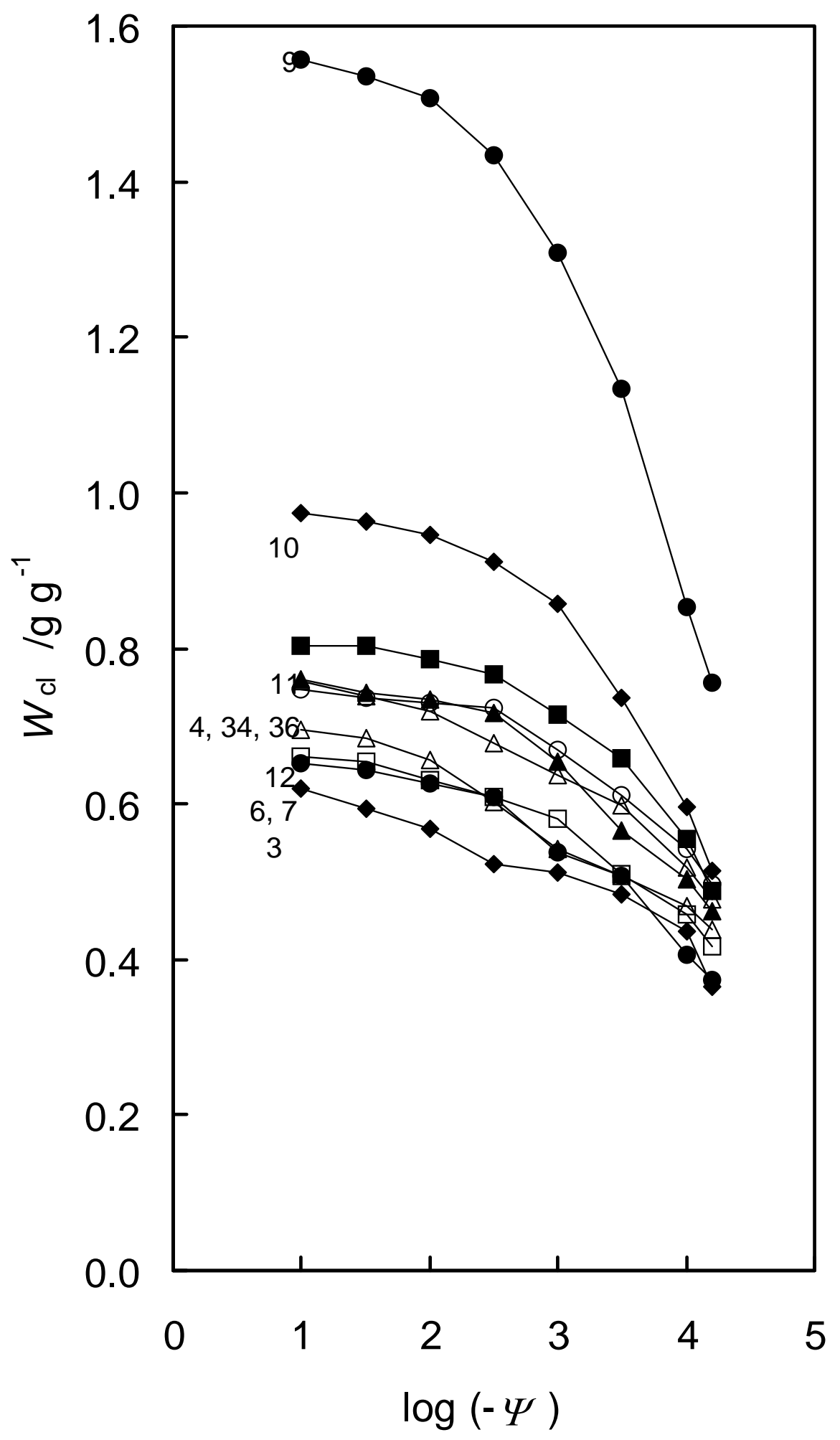

Figure 2a 


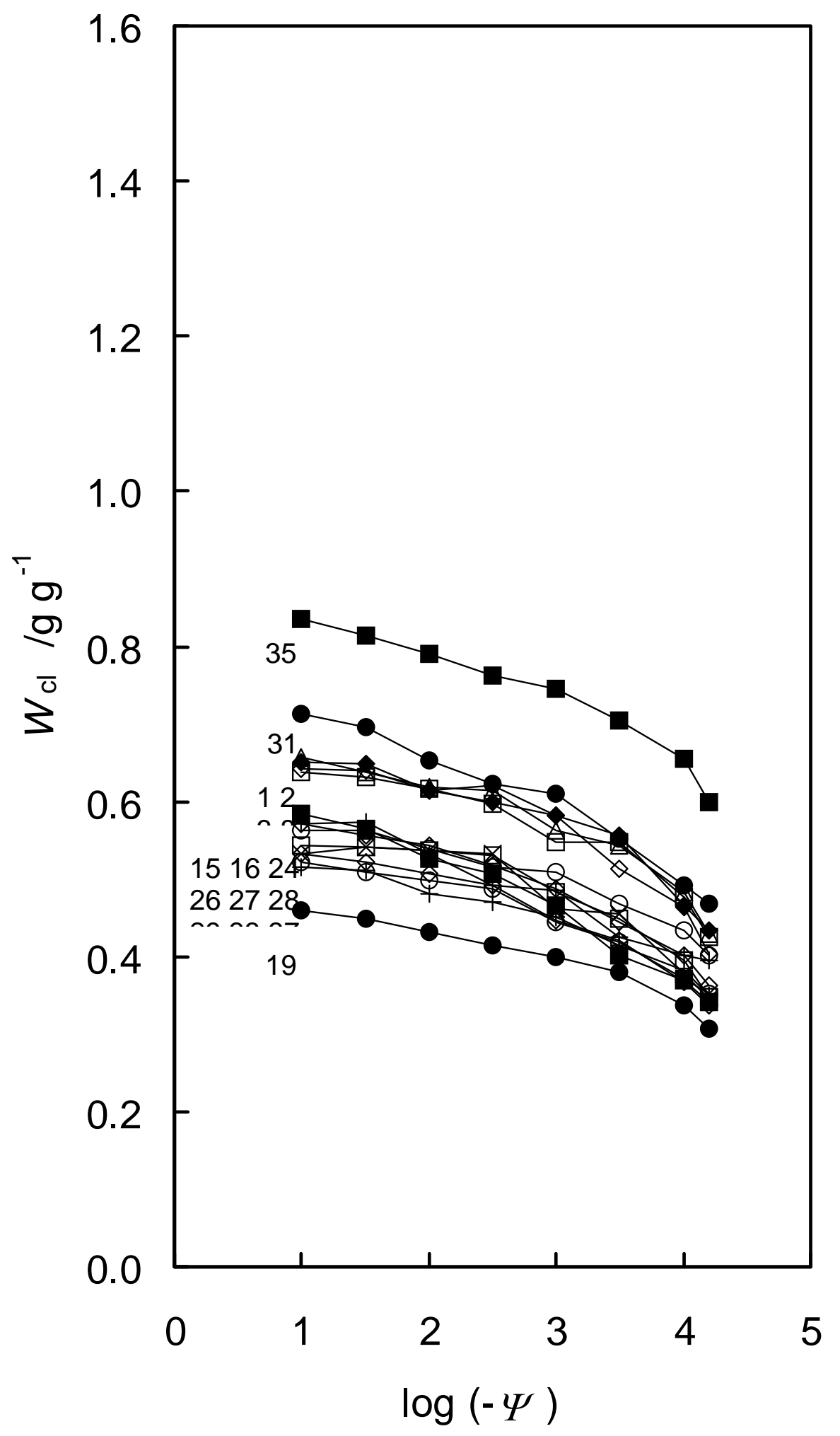

Figure 2b 


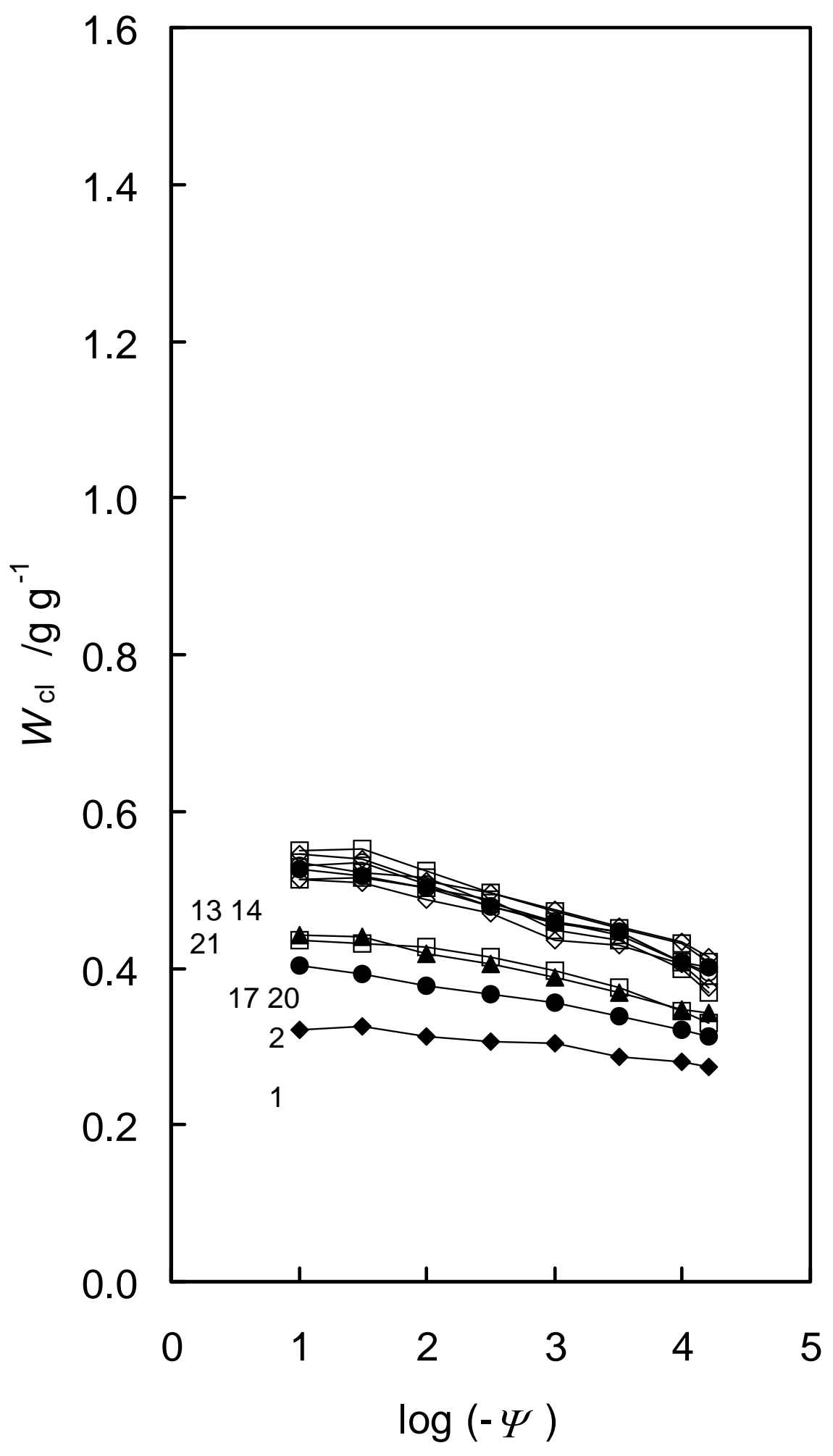

Figure 2c 


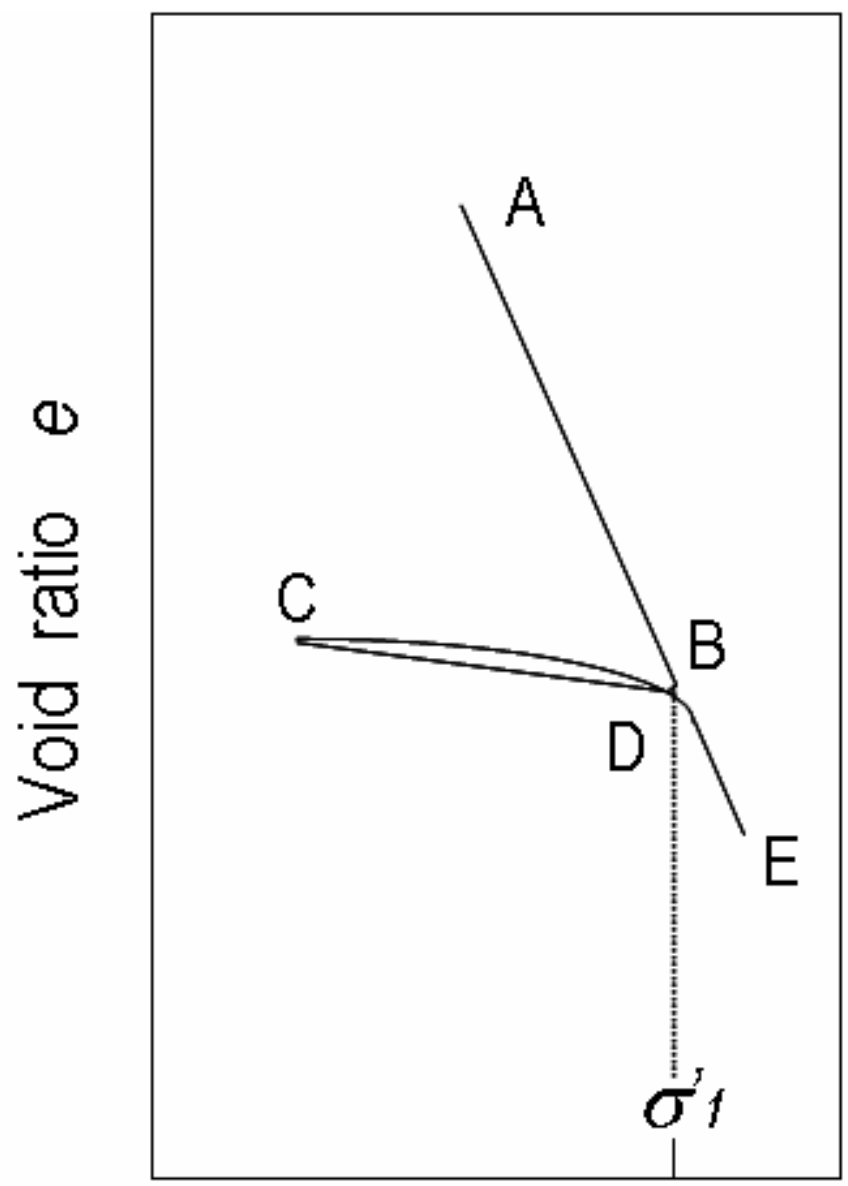

Effective stress $\sigma^{\prime}$

Figure 3 
Table 1 Characteristics of the soils studied.

\begin{tabular}{|c|c|c|c|c|c|c|c|c|}
\hline \multirow[t]{2}{*}{ Horizon } & \multirow[t]{2}{*}{$\begin{array}{l}\text { Drainag } \\
\mathrm{e} \\
\text { class }^{\mathrm{a}}\end{array}$} & Parent material & Depth & $\begin{array}{l}\text { Clay } \\
\text { content }\end{array}$ & $\mathrm{CaCO}_{3}$ & $\begin{array}{l}\text { Organic } \\
\text { carbon }\end{array}$ & $\begin{array}{l}\text { Cation } \\
\text { exchange } \\
\text { capacity }\end{array}$ & $\begin{array}{l}\mathrm{N}_{2} \text {-BET } \\
\text { surface } \\
\text { area }\end{array}$ \\
\hline & & Serie (facies) & $/ \mathrm{cm}$ & & $/ \mathrm{g} \mathrm{g}^{-1}$ & ----------- & $/ \mathrm{mmol}_{+} \mathrm{g}^{-1}$ & $/ \mathrm{m}^{2} \mathrm{~g}^{-1}$ \\
\hline 1 & MWD & Holocene (clay colluvium) & $45-55$ & 0.653 & 0 & 0.0097 & 0.355 & 77.7 \\
\hline 2 & ID & Holocene (clay colluvium) & $75-85$ & 0.582 & 0 & 0.0080 & 0.288 & 67.6 \\
\hline 3 & MWD & Holocene (clay colluvium) & $60-70$ & 0.669 & 0 & 0.0098 & 0.360 & 79.5 \\
\hline 4 & $\mathrm{PD}$ & Holocene (clay colluvium) & $35-50$ & 0.638 & 0 & 0.0101 & 0.248 & 51.6 \\
\hline 5 & ID & Holocene (clay colluvium) & $75-85$ & 0.706 & 0 & 0.0067 & 0.270 & 57.5 \\
\hline 6 & PD & Holocene (clay colluvium) & $45-55$ & 0.671 & 0 & 0.0052 & 0.221 & 47.8 \\
\hline 7 & $\mathrm{PD}$ & Holocene (clay colluvium) & $30-40$ & 0.707 & 0 & 0.0118 & 0.280 & 52.0 \\
\hline 8 & MWD & Holocene (tidal marsh deposit) & $35-45$ & 0.593 & 0.021 & 0.0065 & 0.262 & 61.1 \\
\hline 9 & VPD & Holocene (tidal marsh deposit) & $100-110$ & 0.380 & 0.067 & 0.0034 & 0.198 & 40.1 \\
\hline 10 & VPD & Holocene (tidal marsh deposit) & $82-93$ & 0.594 & 0.027 & 0.0034 & 0.240 & 59.1 \\
\hline 11 & PD & Holocene (tidal marsh deposit) & $55-65$ & 0.577 & 0.021 & 0.0039 & 0.235 & 59.5 \\
\hline 14 & MWD & Pleistocene (silt clay alluvium) & $35-45$ & 0.432 & 0 & 0.0063 & 0.149 & - \\
\hline 15 & MWD & Pleistocene (silt clay alluvium) & $55-70$ & 0.382 & 0 & 0.0020 & 0.142 & 31.4 \\
\hline 16 & MWD & Pleistocene (silt clay alluvium) & $50-60$ & 0.336 & 0 & 0.0013 & 0.158 & 34.7 \\
\hline 17 & MWD & Pleistocene (silt clay alluvium) & $30-60$ & 0.494 & 0 & 0.0037 & 0.112 & 35.1 \\
\hline 18 & ID & Miocene, Helvetian (molasse) & $40-60$ & 0.605 & 0.016 & 0.0009 & 0.152 & 32.1 \\
\hline 19 & MWD & Miocene, Helvetian (molasse) & $15-30$ & 0.545 & 0.009 & 0.0116 & 0.169 & - \\
\hline 20 & $\mathrm{PD}$ & Miocene, Burdigalian (clay deltaic deposit) & $105-130$ & 0.718 & 0 & 0.0023 & 0.347 & - \\
\hline 21 & ID & Miocene, Burdigalian (lagunal clay) & $85-100$ & 0.590 & 0 & 0.0040 & 0.393 & 82.0 \\
\hline 22 & ID & Miocene, Aquitanian (lacustrine marl) & $50-70$ & 0.826 & 0.005 & 0.0074 & 0.474 & 75.0 \\
\hline 23 & $\mathrm{PD}$ & Eocene (clay lacustrine deposit) & $60-95$ & 0.929 & 0 & 0.0022 & 0.350 & 85.5 \\
\hline 24 & MWD & Lower Jurassic, Pliensbachian (marl) & $35-50$ & 0.460 & 0 & 0.0053 & 0.170 & \\
\hline 25 & ID & Lower Jurassic, Sinemurian (marly limestone) & $30-40$ & 0.672 & 0 & 0.0089 & 0.254 & 64.7 \\
\hline 26 & MWD & Lower Jurassic, Sinemurian (marly limestone) & $45-55$ & 0.714 & 0 & 0.0057 & 0.290 & 67.1 \\
\hline 27 & MWD & Lower Jurassic, Sinemurian (marly limestone) & $60-70$ & 0.683 & 0 & 0.0067 & 0.280 & 62.2 \\
\hline 28 & ID & Lower Jurassic, Sinemurian (marly limestone) & $75-85$ & 0.672 & 0 & 0.0052 & 0.255 & 61.5 \\
\hline 29 & MWD & Lower Jurassic, Hettangian (marl) & $40-50$ & 0.533 & 0 & 0.0076 & 0.220 & 41.0 \\
\hline 32 & ID & Middle Triassic, Keuper (marl) & $24-34$ & 0.665 & 0 & 0.0054 & 0.294 & - \\
\hline 33 & ID & Middle Triassic, Keuper (marl) & $60-70$ & 0.568 & 0 & 0.0069 & 0.259 & 65.8 \\
\hline 34 & ID & Middle Triassic, Keuper (marl) & $30-43$ & 0.456 & 0 & 0.0050 & 0.245 & 51.1 \\
\hline 35 & MWD & Middle Triassic, Keuper (marl) & $52-66$ & 0.359 & 0 & 0.0029 & 0.224 & 38.1 \\
\hline 36 & $\mathrm{PD}$ & Middle Triassic, Keuper (marl) & $42-60$ & 0.655 & 0 & 0.0105 & 0.354 & 74.7 \\
\hline 37 & IWD & Middle Triassic, Keuper (marl) & $75-85$ & 0.542 & 0 & 0.0060 & 0.283 & 67.2 \\
\hline Mean & & & & 0.592 & - & 0.0060 & 0.261 & 58.9 \\
\hline Standard deviation & & & & 0.129 & - & 0.0034 & 0.081 & 16.8 \\
\hline Maximum & & & & 0.718 & 0.095 & 0.0118 & 0.474 & 82.0 \\
\hline Minimum & & & & 0.336 & 0 & 0.0013 & 0.112 & 31.4 \\
\hline
\end{tabular}

${ }^{\mathrm{a}}$ MWD: Moderately well drained, ID: Imperfectly drained, PD: Poorly drained, VPD: Very poorly drained. 
Table 2 Specific volume of the soil at field conditions $\left(V_{\mathrm{f}}\right.$, in $\mathrm{cm}^{3}$ per $g$ of oven-dried soil) and $-15000 \mathrm{hPa}$ water potential $\left(V_{15000}\right.$, in $\mathrm{cm}^{3}$ per $\mathrm{g}$ of oven-dried soil), and water retained by the soil at field conditions ( $W_{\mathrm{f}}$, in $\mathrm{g}$ of water per $\mathrm{g}$ of oven-dried soil) and different water potentials ( $W$, in g of water per $g$ of oven-dried soil).

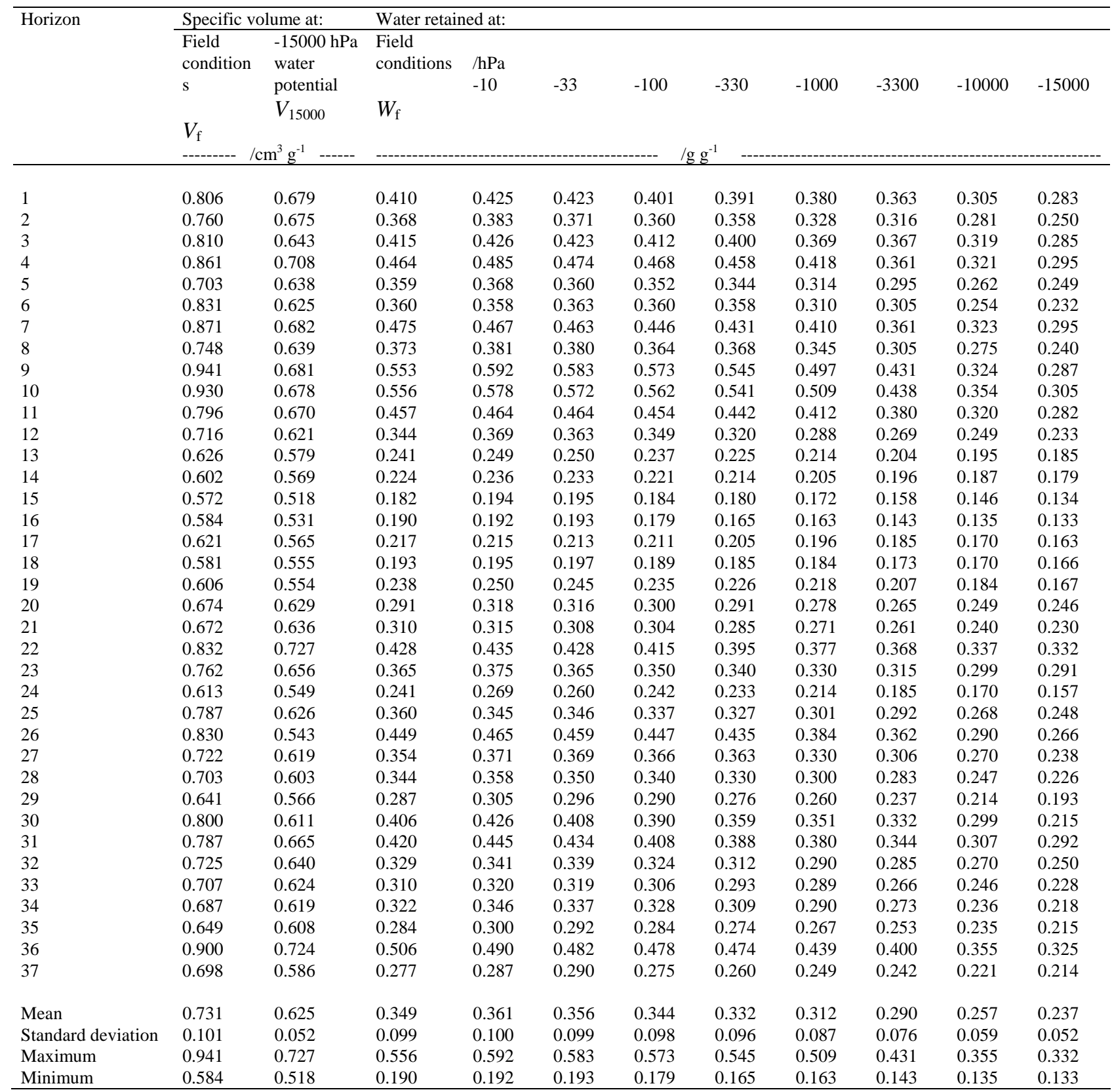


Table 3 Cation exchange capacity $\left(C_{\mathrm{cl}}\right), \mathrm{N}_{2}$-BET surface area $\left(S_{\mathrm{cl}}\right)$, pore volume $\left(V_{\mathrm{p}, \mathrm{cl}}\right)$ of the clay in the horizons studied and difference of $\Delta W_{\mathrm{cl}}$ between -10 and $-15000 \mathrm{hPa}$ water potential $\left(\Delta W_{\mathrm{cl}}\right)$.

\begin{tabular}{|c|c|c|c|c|}
\hline Horizon & $\begin{array}{l}C_{\mathrm{cl}} \\
/ \mathrm{mmol}_{+} \mathrm{g}^{-1}\end{array}$ & $\begin{array}{l}S_{\mathrm{cl}} \\
/ \mathrm{m}^{2} \mathrm{~g}^{-1}\end{array}$ & $\begin{array}{l}V_{\mathrm{p}, \mathrm{cl}} \\
/ \mathrm{cm}^{3} \mathrm{~g}^{-1} \\
\end{array}$ & $\begin{array}{l}\Delta W_{\mathrm{cl}} \\
/ \mathrm{g} \mathrm{g}^{-1}\end{array}$ \\
\hline 1 & 0.544 & 119.0 & 0.657 & 0.217 \\
\hline 2 & 0.495 & 116.2 & 0.658 & 0.229 \\
\hline 3 & 0.538 & 118.8 & 0.647 & 0.211 \\
\hline 4 & 0.389 & 80.9 & 0.757 & 0.298 \\
\hline 5 & 0.382 & 81.4 & 0.504 & 0.169 \\
\hline 6 & 0.329 & 71.2 & 0.550 & 0.188 \\
\hline 7 & 0.396 & 73.6 & 0.699 & 0.243 \\
\hline 8 & 0.442 & 103.0 & 0.626 & 0.238 \\
\hline 9 & 0.521 & 105.5 & 1.484 & 0.803 \\
\hline 10 & 0.404 & 99.5 & 0.931 & 0.460 \\
\hline 11 & 0.407 & 100.5 & 0.726 & 0.315 \\
\hline 12 & 0.463 & 100.9 & 0.638 & 0.256 \\
\hline 13 & 0.320 & 69.8 & 0.550 & 0.141 \\
\hline 14 & 0.345 & - & 0.521 & 0.132 \\
\hline 15 & 0.372 & 82.2 & 0.510 & 0.165 \\
\hline 16 & 0.470 & 103.3 & 0.616 & 0.176 \\
\hline 17 & 0.227 & 71.1 & 0.494 & 0.105 \\
\hline 18 & 0.251 & 53.1 & 0.337 & 0.048 \\
\hline 19 & 0.310 & - & 0.430 & 0.152 \\
\hline 20 & 0.483 & - & 0.414 & 0.100 \\
\hline 21 & 0.666 & 139.0 & 0.500 & 0.144 \\
\hline 22 & 0.574 & 115.0 & 0.551 & 0.125 \\
\hline 23 & 0.377 & 92.0 & 0.414 & 0.090 \\
\hline 24 & 0.370 & - & 0.513 & 0.243 \\
\hline 25 & 0.378 & 96.3 & 0.610 & 0.144 \\
\hline 26 & 0.406 & 93.9 & 0.634 & 0.279 \\
\hline 27 & 0.410 & 91.1 & 0.505 & 0.195 \\
\hline 28 & 0.379 & 91.5 & 0.485 & 0.196 \\
\hline 29 & 0.413 & 76.9 & 0.495 & 0.210 \\
\hline 30 & 0.441 & 92.0 & 0.616 & 0.255 \\
\hline 31 & 0.609 & 117.0 & 0.657 & 0.245 \\
\hline 32 & 0.442 & - & 0.523 & 0.137 \\
\hline 33 & 0.518 & 115.8 & 0.581 & 0.162 \\
\hline 34 & 0.537 & 112.1 & 0.680 & 0.281 \\
\hline 35 & 0.624 & - & 0.758 & 0.237 \\
\hline 36 & 0.540 & 114.0 & 0.798 & 0.252 \\
\hline 37 & 0.522 & 124.0 & 0.518 & 0.135 \\
\hline Mean & 0.440 & 97.4 & 0.610 & 0.216 \\
\hline Standard deviation & 0.101 & 19.5 & 0.190 & 0.127 \\
\hline Maximum & 0.666 & 139.0 & 1.484 & 0.803 \\
\hline Minimum & 0.227 & 53.1 & 0.337 & 0.048 \\
\hline
\end{tabular}


Table 4 Regression equations between the water retained by clay $\left(W_{\mathrm{cl}}\right)$ at different water potentials and the clay fabric $\left(V_{\mathrm{p}, \mathrm{cl}}\right)$

\begin{tabular}{llll}
\hline Water potential & Regression equation & $\begin{array}{l}\text { Variance } \\
\text { accounted } \\
\text { for }\end{array}$ & $N$ \\
& & $/ \%$ & \\
/hPa & & 96 & 37 \\
\hline-10 & $W_{\mathrm{cl}}=0.041+0.913 V_{\mathrm{p}, \mathrm{cl}}$ & 96 & 37 \\
-33 & $W_{\mathrm{cl}}=0.036+0.934 V_{\mathrm{p}, \mathrm{cl}}$ & 96 & 37 \\
-100 & $W_{\mathrm{cl}}=0.050+0.940 V_{\mathrm{p}, \mathrm{cl}}$ & 96 & 37 \\
-330 & $W_{\mathrm{cl}}=0.046+0.984 V_{\mathrm{p}, \mathrm{cl}}$ & 96 & 37 \\
-1000 & $W_{\mathrm{cl}}=0.026+1.084 V_{\mathrm{p}, \mathrm{cl}}$ & 94 & 37 \\
-3300 & $W_{\mathrm{cl}}=-0.029+1.281 V_{\mathrm{p}, \mathrm{cl}}$ & 89 & 37 \\
-10000 & $W_{\mathrm{cl}}=-0.161+1.740 V_{\mathrm{p}, \mathrm{cl}}$ & 86 & 37 \\
-15000 & $W_{\mathrm{cl}}=-0.211+2.010 V_{\mathrm{p}, \mathrm{cl}}$ & 86 & \\
\hline
\end{tabular}




\begin{tabular}{|c|c|c|c|c|c|c|c|c|}
\hline \multirow{2}{*}{$\begin{array}{l}\text { Difference of } \\
W_{\mathrm{cl}} \text { between }-10 \\
\text { and }-15000 \mathrm{hPa}\end{array}$} & \multirow[t]{2}{*}{ Horizons } & \multicolumn{7}{|c|}{ Mean absolute value of the slope between: } \\
\hline & & $\begin{array}{l}-10 \text { and } \\
-33 \mathrm{hPa}\end{array}$ & $\begin{array}{l}-33 \text { and } \\
-100 \mathrm{hPa}\end{array}$ & $\begin{array}{l}-100 \text { and } \\
-330 \mathrm{hPa}\end{array}$ & $\begin{array}{l}-330 \text { and } \\
-1000 \mathrm{hPa}\end{array}$ & $\begin{array}{l}-1000 \text { and } \\
-3300 \mathrm{hPa}\end{array}$ & $\begin{array}{l}-3300 \text { and } \\
10000 \mathrm{hPa}\end{array}$ & $\begin{array}{l}-10000 \text { and } \\
-15000 \mathrm{hPa}\end{array}$ \\
\hline \multirow[t]{2}{*}{$/ \mathrm{g} \mathrm{g}^{-1}$} & & ------- & & - & \multirow[t]{2}{*}{$/ \mathrm{g} \mathrm{g}^{-1}$} & & & \\
\hline & & - & & & & & & \\
\hline$>0.250$ & $\begin{array}{l}4,6,7,9,10,11 \\
12,3034,36\end{array}$ & $0.027(0.005)$ & $0.036(0.004)$ & $0.065(0.013)$ & $0.108(0.019)$ & $0.135(0.029)$ & $0.186(0.044)$ & $0.266(0.035)$ \\
\hline $0.150-0.250$ & $\begin{array}{l}1,2,3,8,15,16, \\
19,24,26,27,28 \\
29,31,33,35,37\end{array}$ & $0.016(0.005)$ & $0.046(0.006)$ & $0.031(0.006)$ & $0.065(0.010)$ & $0.070(0.010)$ & $0.103(0.009)$ & $0.178(0.019)$ \\
\hline$<0.150$ & $\begin{array}{l}5,13,14,17,18, \\
20,21,22,23,25, \\
32\end{array}$ & $0.006(0.003)$ & $0.036(0.005)$ & $0.037(0.005)$ & $0.042(0.006)$ & $0.033(0.003)$ & $0.052(0.006)$ & $0.077(0.014)$ \\
\hline
\end{tabular}

Table 5 Mean absolute value of the slope $\left(\left|\Delta W_{\mathrm{cl}} / \Delta \log -\Psi\right|\right.$ in $g$ of water per g of dried clay and unit of log- $\left.\Psi\right)$ and standard error (between brackets) for the water retention curve of the clay within every group of horizons defined with respect to the difference of $W_{\mathrm{cl}}\left(\Delta W_{\mathrm{cl}}\right.$, in g of water per g of oven-dried clay) between -10 and $-15000 \mathrm{hPa}$ water potential. 